\title{
The Isorhamnetin-Containing Fraction of Philippine Honey Produced by the Stingless Bee Tetragonula biroi Is an Antibiotic against Multidrug-Resistant Staphylococcus aureus
}

\author{
Angelica Faith L. Suarez ${ }^{1}$, April Dawn G. Tirador ${ }^{1}$, Zenith M. Villorente ${ }^{2}$, Cathrina F. Bagarinao ${ }^{2}$,
} Jan Vincent N. Sollesta ${ }^{2}$, Gerard G. Dumancas ${ }^{3,4}{ }^{-}$, Zhe Sun ${ }^{5}$, Zhao Qi Zhan ${ }^{5}$, Jonel P. Saludes ${ }^{4,6,7} \mathbb{1}$ and Doralyn S. Dalisay $1,4,8, *$ (i)

check for

updates

Citation: Suarez, A.F.L.; Tirador, A.D.G.; Villorente, Z.M.; Bagarinao, C.F.; Sollesta, J.V.N.; Dumancas, G.G.; Sun, Z.; Zhan, Z.Q.; Saludes, J.P.; Dalisay, D.S. The Isorhamnetin-Containing Fraction of Philippine Honey Produced by the Stingless Bee Tetragonula biroi Is an Antibiotic against

Multidrug-Resistant Staphylococcus aureus. Molecules 2021, 26, 1688. https://doi.org/10.3390/ molecules26061688

Academic Editors: Soraia I. Falcão and Juraj Majtan

Received: 18 January 2021

Accepted: 5 March 2021

Published: 17 March 2021

Publisher's Note: MDPI stays neutral with regard to jurisdictional claims in published maps and institutional affiliations.

Copyright: (c) 2021 by the authors. Licensee MDPI, Basel, Switzerland. This article is an open access article distributed under the terms and conditions of the Creative Commons Attribution (CC BY) license (https:/ / creativecommons.org/licenses/by/ $4.0 /)$.
1 Center for Chemical Biology and Biotechnology (C2B2), University of San Agustin, Iloilo City 5000, Philippines; aicasuarez03@gmail.com (A.F.L.S.); tiradorapril@gmail.com (A.D.G.T.)

2 Maridan Industries, Inc., Jaro, Iloilo City 5000, Philippines; zmvillorente@maridan.com.ph (Z.M.V.); cfbagarinao@maridan.com.ph (C.F.B.); jvsollesta@maridan.com.ph (J.V.N.S.)

3 Department of Mathematics and Physical Sciences, Louisiana State University at Alexandria, Alexandria, LA 71302, USA; gdumancas@lsua.edu

4 Balik Scientist Program, Philippine Council for Health Research and Development (PCHRD), Department of Science and Technology, Bicutan, Taguig City 1631, Philippines; jsaludes@usa.edu.ph

5 Shimadzu Asia Pacific (SAP), Singapore Science Park I, Singapore 118264, Singapore; sunzhe@shimadzu.com.sg (Z.S.); zhaoqi@shimadzu.com.sg (Z.Q.Z.)

6 Center for Natural Drug Discovery and Development (CND3), University of San Agustin, Iloilo City 5000, Philippines

7 Department of Chemistry, College of Liberal Arts, Sciences, and Education, University of San Agustin, Iloilo City 5000, Philippines

8 Department of Biology, College of Liberal Arts, Sciences, and Education, University of San Agustin, Iloilo City 5000, Philippines

* Correspondence: ddalisay@usa.edu.ph; Tel.: +63-33-501-0350

Abstract: Honey exhibits antibacterial and antioxidant activities that are ascribed to its diverse secondary metabolites. In the Philippines, the antibacterial and antioxidant activities, as well as the bioactive metabolite contents of the honey, have not been thoroughly described. In this report, we investigated the in vitro antibacterial and antioxidant activities of honey from Apis mellifera and Tetragonula biroi, identified the compound responsible for the antibacterial activity, and compared the observed bioactivities and metabolite profiles to that of Manuka honey, which is recognized for its antibacterial and antioxidant properties. The secondary metabolite contents of honey were extracted using a nonionic polymeric resin followed by antibacterial and antioxidant assays, and then spectroscopic analyses of the phenolic and flavonoid contents. Results showed that honey extracts produced by T. biroi exhibits antibiotic activity against Staphylococcal pathogens as well as high antioxidant activity, which are correlated to its high flavonoid and phenolic content as compared to honey produced by A. mellifera. The bioassay-guided fractionation paired with Liquid Chromatography Mass Spectrometry (LCMS) and tandem MS analyses found the presence of the flavonoid isorhamnetin (3-methylquercetin) in T. biroi honey extract, which was demonstrated as one of the compounds with inhibitory activity against multidrug-resistant Staphylococcus aureus ATCC BAA-44. Our findings suggest that Philippine honey produced by T. biroi is a potential nutraceutical that possesses antibiotic and antioxidant activities.

Keywords: Philippine honey; Tetragonula biroi; stingless bee; flavonoids; antibacterial; antioxidant; isorhamnetin; phenolics

\section{Introduction}

The health-promoting properties of honey are associated with plant secondary metabolites that are gathered by honey bees concomitant to the collection of flower nectars or 
honeydew. In addition to its traditional household use as a sweetener, honey is often recognized as an alternative nutraceutical that exhibits a broad spectrum of in vitro activities such as antibacterial, antioxidant, anti-inflammatory, immunomodulatory, anticancer, anti-glycemic, prebiotic, and antiviral activities [1-8]. Correlated with honey's biological activities is the diversity of its secondary metabolite composition. This chemodiversity is influenced by several factors, such as plant source, geographical location, entomological origin, honey collection, and extraction processes [8-13]. Aside from being a supersaturated solution of glucose and fructose, the chemical composition of honey is complex and variable, which is strongly dependent on its geographical and botanical origins [14]. Estimates indicate that honey is composed of about 200 other minor metabolites that are usually present between 0.01 and $10 \mathrm{ppm}$ [15]. Honey contains plant-based polyphenols, aromatic acids, esters, and flavonoids that are vital for honey's antioxidant and antibacterial properties [16-22]. Aside from phenolic compounds, honey also contains enzymes such as glucose oxidase, diastase, invertase, catalase, and peroxidase that are also responsible for antibacterial activity $[1,2,6]$. Other bioactive constituents such as organic acids, trace elements, vitamins, amino acids, and proteins were also found $[1,2,19]$.

An abundance of information on the evaluation of honey's antimicrobial and antioxidant properties is available $[3,7,8,16,20,23]$. However, it is notable that the observed bioactivities are dependent on and as variable as the botanical and geographical origins, and climatic conditions $[8-11,13,14,23]$. In the Philippines, the majority of honey is produced by $A$. mellifera and, to a limited extent, by the indigenous stingless bee Tetrogonula biroi (synonymous to Trigona biroi) [24]. Reports showed that honeys produced by the stingless bee T. biroi were produced in Southern Luzon area in the Philippines, particularly in the Laguna, Quezon, and Sorsogon regions, and Western Visayas area specifically in Iloilo and Negros Occidental provinces [24-27]. Conversely, A. mellifera honey is produced in the Southern Mindanao (Davao) [28] and Southern Luzon areas in Laguna [29]. These local honeys are used as sweeteners, but their potential as nutraceutical products with health and therapeutic benefits has not been thoroughly described. As part of our bioactive natural products program, we performed a small-scale screening of Philippine honeys samples produced by A. mellifera and T. biroi for their antibacterial and antioxidant activities, and determined their total phenolics and total flavonoid contents. We used Manuka honey, a widely recognized nutraceutical product for its antibacterial and antioxidant properties, as a reference honey $[30,31]$. Lastly, we identified an antibiotic compound from the honey produced by Philippine stingless bee $T$. biroi that possesses high antibacterial activity against $S$. aureus ATCC BAA-44, a multidrug resistant strain. The overall findings of our study strongly support and validate that Philippine honey produced by the stingless bee $T$. biroi is a nutraceutical with demonstrated in vitro therapeutic potential.

\section{Results}

\subsection{Antibacterial Activities}

The honey crude extracts isolated from 15 local apiaries in the Philippines (Table 1, Figure S1) were tested against five target Staphylococcus pathogens, namely S. aureus ATCC 25923, S. aureus ATCC BAA-44, S. aureus ATCC 6538, S. saprophyticus clinical isolate, and S. epidermidis clinical isolate using agar well diffusion assay. The antibacterial assay results showed that Philippine honey SL 01 crude extract produced by the stingless bee T. biroi showed inhibitory activity against all five tested pathogens (Table 2). It exhibited the highest activity with $12.5 \mathrm{~mm}$ zone of inhibition (ZOI) against $S$. aureus ATCC BAA-44, a multidrug-resistant pathogen. It showed minimal activities ( 3.5 to $5.0 \mathrm{~mm} \mathrm{ZOI)} \mathrm{against} \mathrm{the}$ remaining Staphylococcus pathogens. The SL 01 crude extract was the only sample (7\% hit rate) with activity against $S$. aureus ATCC BAA-44, S. aureus ATCC 25923, and S. epidermidis clinical isolate (Table 2$)$. There were four ( $27 \%$ hit rate) honey extracts that showed activity against $S$. aureus ATCC 6538 , namely NM 01 , SL 01 , SEM 01 , and WV 01 , with weak activity of 1.5 to $3.5 \mathrm{~mm}$ ZOI. Twelve ( $80 \%$ hit rate) extracts showed activity (ZOI 2.5 to $5.0 \mathrm{~mm}$ ) against $S$. saprophyticus. NL 02 and WV 02 honey extracts were found to be inactive against 
all five tested pathogens. Interestingly, none of the Manuka honey crude extracts showed antibacterial activities against all five tested pathogens and showed only minimal activity (ZOI 2.0 to $2.5 \mathrm{~mm}$ ) against the S. aureus ATCC BAA-44. Notably, SL 01 honey extract produced by the stingless bee $T$. biroi possessed antibiotic activity against all five tested Staphylococcal pathogens, while the remaining honey samples produced by A. mellifera showed selective activity against the tested pathogens (Table 2).

Table 1. Floral sources, harvesting region, and honey bee species.

\begin{tabular}{|c|c|c|c|}
\hline Honey Sample (Code) & Floral Source & Geographical Origin & Bee Species \\
\hline MGO $550^{\mathrm{a}}$ & Manuka tree & New Zealand & Apis mellifera \\
\hline UMF $15^{\text {a }}$ & Manuka tree & New Zealand & Apis mellifera \\
\hline NL 01 & Sunflower & NL, Philippines & Apis mellifera \\
\hline NL 02 & Sunflower (mostly), trumpet flowers, squash, calliandra, coffee & NL, Philippines & Apis mellifera \\
\hline NM 01 & Wild flowers, falcata & NM, Philippines & Apis mellifera \\
\hline NM 02 & Cassava, minimal sunflowers & NM, Philippines & Apis mellifera \\
\hline NM 03 & Pineapples & NM, Philippines & Apis mellifera \\
\hline NM 04 & Pineapples & NM, Philippines & Apis mellifera \\
\hline NM 05 & Pineapples, minimal sunflowers & NM, Philippines & Apis mellifera \\
\hline SEM 01 & Banana trees, coconuts, palm trees, Philippine lime & SM, Philippines & Apis mellifera \\
\hline SL 01 & Coconut, bananas, mangoes & SL, Philippines & Tetragonula biroi \\
\hline SL 02 & $\begin{array}{c}\text { Coconut, acacia, tamarind, sapodilla fruit, mangrove, } \\
\text { kerson fruit }\end{array}$ & SL, Philippines & Apis mellifera \\
\hline SL 03 & $\begin{array}{l}\text { Coconut, mahogany, mangoes, dragon fruit, bamboo, peanut } \\
\text { grass, other flowering plants }\end{array}$ & SL, Philippines & Apis mellifera \\
\hline SL 04 & Acacia, mangoes, coconut, tamarind, avocadoes, coffee & SL, Philippines & Apis mellifera \\
\hline SL 05 & $\begin{array}{c}\text { Kerson fruit, mangoes, coconuts, calamansi, } \\
\text { mangroves, papaya }\end{array}$ & SL, Philippines & Apis mellifera \\
\hline WV 01 & Mahogany, Philippine lime, cucumber tree, yellow bell plant & WV, Philippines & Apis mellifera \\
\hline WV 02 & Banana, coconut, cosmos flower, nipa palm and mangoes & WV, Philippines & Apis mellifera \\
\hline
\end{tabular}

a Manuka honey-used as a reference honey. NL-Northern Luzon; NM-Northern Mindanao; SL-Southern Luzon; SM-Southern Mindanao; WV-Western Visayas.

Table 2. Antibacterial Activity of Honey Extracts Against Staphylococcal Pathogens.

\begin{tabular}{|c|c|c|c|c|c|}
\hline \multirow{2}{*}{ Honey Samples a } & \multicolumn{5}{|c|}{ Antibiotic Activity Zone of Inhibition, $\mathrm{mm}$} \\
\hline & $\begin{array}{c}\text { S. aureus } \\
\text { ATCC BAA-44 }\end{array}$ & $\begin{array}{c}\text { S. aureus } \\
\text { ATCC } 25923\end{array}$ & $\begin{array}{l}\text { S. aureus } \\
\text { ATCC } 6538\end{array}$ & $\begin{array}{l}\text { S. saprophyticus } \\
\text { Clinical Isolate }\end{array}$ & $\begin{array}{l}\text { S. epidermidis } \\
\text { Clinical Isolate }\end{array}$ \\
\hline Tetracycline (standard) ${ }^{b}$ & $22.0 \pm 0.7$ & $26.5 \pm 1.4$ & $24 \pm 0.0$ & $33 \pm 2.8$ & $36.5 \pm 2.8$ \\
\hline $\mathrm{DMSO}^{\mathrm{c}}$ & $(-)$ & $(-)$ & $(-)$ & $(-)$ & $(-)$ \\
\hline Manuka health MGO 550 d & $2.5 \pm 0.7$ & $(-)$ & $(-)$ & $6.0 \pm 0.0$ & $2.5 \pm 0.7$ \\
\hline Comvita UMF $15^{\mathrm{d}}$ & $2.0 \pm 0.0$ & $(-)$ & $(-)$ & $5.8 \pm 1.1$ & $2.5 \pm 0.7$ \\
\hline NM 01 & $(-)$ & $(-)$ & $1.5 \pm 2.1$ & $4.0 \pm 1.4$ & $(-)$ \\
\hline NM 02 & $(-)$ & $(-)$ & $(-)$ & $4.5 \pm 0.7$ & $(-)$ \\
\hline NM 03 & $(-)$ & $(-)$ & $(-)$ & $3.5 \pm 0.7$ & $(-)$ \\
\hline NM 04 & $(-)$ & $(-)$ & $(-)$ & $3.5 \pm 2.1$ & $(-)$ \\
\hline NM 05 & $(-)$ & $(-)$ & $(-)$ & $2.5 \pm 0.7$ & $(-)$ \\
\hline SL 01 & $12.5 \pm 0.7$ & $4.8 \pm 0.4$ & $3.5 \pm 0.7$ & $5.0 \pm 1.4$ & $4.5 \pm 0.7$ \\
\hline SL 02 & $(-)$ & $(-)$ & $(-)$ & $3.0 \pm 1.4$ & $(-)$ \\
\hline SL 03 & $(-)$ & $(-)$ & $(-)$ & $5.0 \pm 0.0$ & $(-)$ \\
\hline SL 04 & $(-)$ & $(-)$ & $(-)$ & $5.0 \pm 1.4$ & $(-)$ \\
\hline SL 05 & $(-)$ & $(-)$ & $(-)$ & $3.3 \pm 0.4$ & $(-)$ \\
\hline SEM 01 & $(-)$ & $(-)$ & $2.5 \pm 0.7$ & $2.5 \pm 0.7$ & $(-)$ \\
\hline NL 01 & $(-)$ & $(-)$ & $(-)$ & $4.3 \pm 0.4$ & $(-)$ \\
\hline NL 02 & $(-)$ & $(-)$ & $(-)$ & $(-)$ & $(-)$ \\
\hline WV 01 & $(-)$ & $(-)$ & $2.0 \pm 0.0$ & $(-)$ & $(-)$ \\
\hline WV 02 & $(-)$ & $(-)$ & $(-)$ & $(-)$ & $(-)$ \\
\hline $\begin{array}{c}\% \text { Hit rate } \\
\text { (Philippine honey } n=15 \text { ) }\end{array}$ & 7 & 7 & 27 & 80 & 7 \\
\hline
\end{tabular}

${ }^{\mathrm{a}}$ Honey extract samples $(10 \mathrm{mg} /$ well $) ;{ }^{\mathrm{b}}$ Tetracycline $(0.25 \mathrm{mg} /$ well $)$, positive control; ${ }^{\mathrm{c}}$ DMSO, negative control; ${ }^{\mathrm{d}}$ Manuka honey from New Zealand used as reference; (-) - no activity. 


\subsection{Antioxidant Activities}

To evaluate if Philippine honey crude extracts possess antioxidant activities, 2,2diphenyl-1-picrylhydrazyl (DPPH) radical scavenging assay was performed. Among the honey extracts tested for antioxidant activity, SL 01 produced by the stingless bee T. biroi exhibited the highest activity at $65.71 \%$ inhibition, followed by SL 02 produced by $A$. mellifera, with $57.94 \%$ inhibition. There was a significant difference between SL 01 and SL 02 honey extracts antioxidant activities as shown by $p \leq 0.05$. The rest of the Philippine honey extracts showed minimal antioxidant activity $(<50 \%)$ when referred to the positive control, ascorbic acid (Figure 1). Interestingly, the Manuka honey crude extracts showed minimal activity as well at $<50 \%$ antioxidant activity.

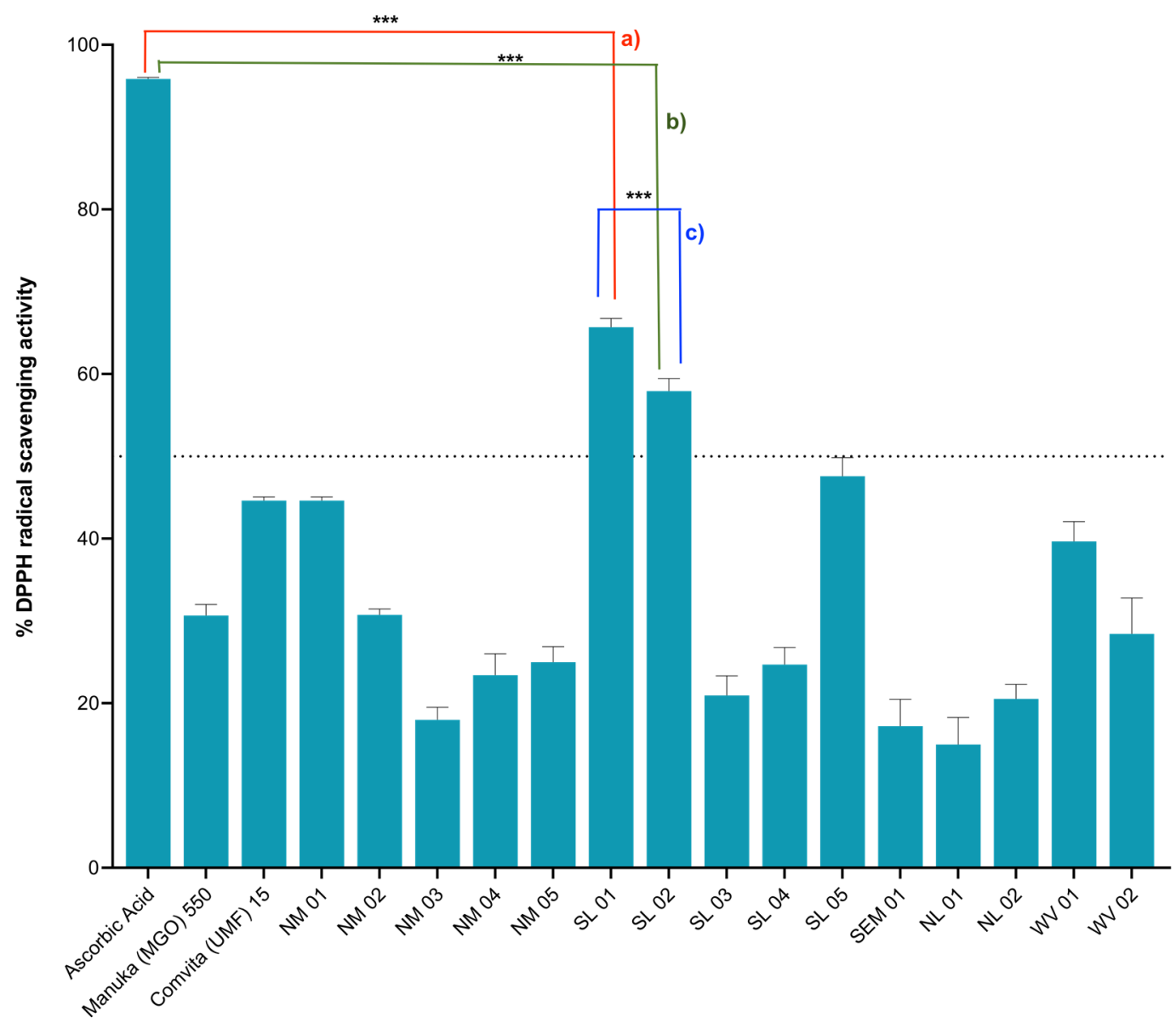

Figure 1. 2,2-diphenyl-1-picrylhydrazyl (DPPH) Scavenging Activity of Honey Crude Extracts. Ascorbic acid, $1 \mathrm{mg} / \mathrm{mL}$ (positive control); Honey extracts, $5 \mathrm{mg} / \mathrm{mL}$. (a) Two tailed $p$ value $=0.0008$ for ascorbic acid and SL01, (b) Two tailed $p$ value $=0.0013$ for ascorbic acid and SL02, (c) Two tailed $p$ value $=0.0040$ for SL01 and SL02. ${ }^{* *}$ indicate the significant difference $(p \leq 0.05)$.

\subsection{Flavonoid and Phenolic Contents and their Correlation with Bioactivities}

The phenolic and flavonoid contents of honey extracts (Table 3) were quantified using spectroscopic techniques. Our findings revealed that Philippine honey extracts contain phenolics at a concentration range of 236-165 $\mu \mathrm{g}$ Gallic Acid Equivalent (GAE)/mg crude extract. Philippine honeys with high phenolic contents were NM 02, NM 05, SL 05, NL 02, SL 04, and SL 01 samples (Table 3). Interestingly, the SL 01 honey from stingless bee T. biroi showed the highest flavonoid content at $216.14 \mu \mathrm{g}$ Quercetin Equivalent $(\mathrm{QE}) / \mathrm{mg}$ (Table 3) and the remaining honey samples showed low flavonoid content with $<30 \mu \mathrm{g}$ $\mathrm{QE} / \mathrm{mg}$. Conversely, Manuka honey extracts showed low levels of phenolic (184-170 $\mu \mathrm{g}$ $\mathrm{GAE} / \mathrm{mg}$ ) and flavonoid (21-26 $\mu \mathrm{g} \mathrm{QE} / \mathrm{mg})$ contents. 
Table 3. Total Phenolic and Flavonoid Content of Honey Crude Extracts.

\begin{tabular}{|c|c|c|}
\hline Honey Samples & $\mu \mathrm{g} \mathrm{GAE} / \mathrm{mg}^{\mathrm{a}}$ & $\mu \mathrm{g} Q E / \mathrm{mg}^{\mathrm{b}}$ \\
\hline MGO 550 & $184.655 \pm 5.226$ & $21.857 \pm 0.006$ \\
\hline UMF 15 & $170.500 \pm 15.144$ & $26.857 \pm 0.009$ \\
\hline NL 01 & $204.872 \pm 21.868$ & $19.000 \pm 0.016$ \\
\hline NL 02 & $233.246 \pm 3.918$ & $8.762 \pm 0.002$ \\
\hline NM 01 & $200.402 \pm 3.788$ & $10.667 \pm 0.003$ \\
\hline NM 02 & $236.192 \pm 1.371$ & $6.857 \pm 0.001$ \\
\hline NM 03 & $180.955 \pm 23.681$ & $9.714 \pm 0.001$ \\
\hline NM 04 & $165.884 \pm 0.222$ & $7.333 \pm 0.002$ \\
\hline NM 05 & $235.739 \pm 1.278$ & $10.905 \pm 0.005$ \\
\hline SEM 01 & $224.221 \pm 13.914$ & $13.048 \pm 0.001$ \\
\hline SL 01 & $227.128 \pm 11.064$ & $216.143 \pm 0.016$ \\
\hline SL 02 & $224.809 \pm 3.190$ & $14.714 \pm 0.003$ \\
\hline SL 03 & $192.081 \pm 5.431$ & $12.571 \pm 0.004$ \\
\hline SL 04 & $229.846 \pm 0.222$ & $21.619 \pm 0.004$ \\
\hline SL 05 & $234.569 \pm 3.063$ & $9.952 \pm 0.002$ \\
\hline WV 01 & $192.973 \pm 15.720$ & $11.143 \pm 0.002$ \\
\hline WV 02 & $218.138 \pm 3.909$ & $8.048 \pm 0.001$ \\
\hline
\end{tabular}

a Gallic Acid Equivalent-unit for Total Phenolic Content per mg crude extract; ${ }^{\mathrm{b}}$ Quercetin Equivalent—unit for Total Flavonoids per mg crude extract.

Hierarchical clustering was constructed to correlate the flavonoids and phenolics contents in honey extracts with its observed antibacterial and antioxidant activities (Figure 2). The between-groups linkage method was chosen as a complete linkage and the City Block Distance was selected to establish clusters. A dendrogram provided the visual representation of the relationship of bioactivities as affected by total phenolic content and flavonoid content. The resulting hierarchical cluster heat-map in Figure 2 produced well-defined clusters that were grouped into five main clusters. Honey SL 01 (stingless bee T. biroi) was the only sample categorized in cluster 1 with a longer distance of similarity to the four clusters. Cluster 1 showed activity against all five tested pathogens, with the highest antioxidant activity, a high total phenolic content (TPC), and the highest flavonoid content. To note, SL 01 honey bees (T. biroi) forage on coconut trees, bananas, and mangoes (Table 1). The Manuka honey samples (MGO 550 and UMF 15) were grouped together into cluster 2, indicating similarity in bioactivity and phenolics and flavonoid contents. The A. mellifera producing this honey forages on the manuka tree (Table 1). The cluster 3 was composed of NL 02, WV 01, and SEM 01. These samples possess antibacterial activities towards two (WV 01) or three (SEM 01) target tested pathogens and moderate antioxidant activities (Figure 2). Interestingly, NL 02 showing no antibacterial activities was included in this cluster. The floral sources for this cluster are various plants such as bananas, coconuts, sunflowers, trumpet flowers, and squash (Table 1). Honey samples WV 02, NM 05, SL 02, and SL 05 were categorized in cluster 4 . These samples possess moderate activity against $S$. saprophyticus, weaker antioxidant activity, and a high phenolic content (between 235 and $220 \mu \mathrm{g} \mathrm{GAE} / \mathrm{mg}$ sample). Members in cluster 4 are honey samples with bees foraging in various plants such as pineapples, coconuts, mangroves, trumpet flowers, and kerson fruit (Table 1). The remaining samples with the weakest biological activities and the least flavonoid contents were grouped in cluster 5 . Four of these samples (NM 01, NM 02, NM 03, NM 04, and NL 01) were produced by A. mellifera bees foraging either in pineapples or, sunflower (Table 1). Samples SL 03 and SL 04 were honeys made by A. mellifera from various floral sources. 


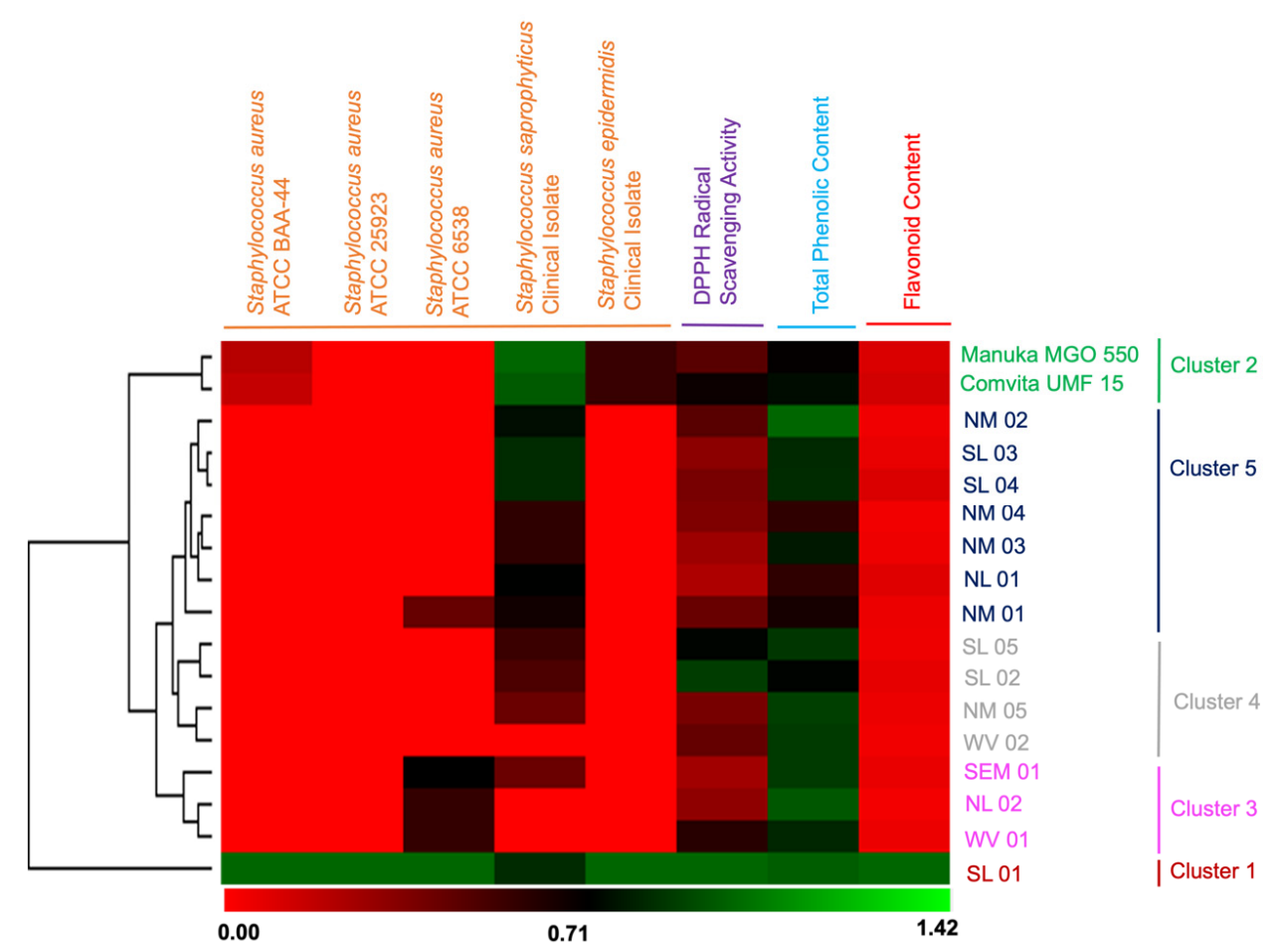

Figure 2. Heat map and hierarchical clustering presentation of antibacterial activity, antioxidant activity, total phenolic content, and flavonoid content of honey crude extract samples.

\subsection{Purification of the Antibiotic Component from T. biroi Honey}

Since T. biroi honey extract (SL 01) inhibited the growth of all the tested organisms, including the multidrug-resistant $S$. aureus ATCC BAA-44 with Minimum Inhibitory Concentration, MIC at $1250 \mu \mathrm{g} / \mathrm{mL}$, it was purified by Gel Permeation Chromatography (GPC) using Sephadex LH-20 and yielded 69 fractions of $7 \mathrm{~mL}$ each that were then pooled to eight fractions (Table 4). The bulk of the crude extract was found in Fraction 4 with $219.2 \mathrm{mg}$, $42.98 \%$ yield. Subsequently, these eight pooled GPC fractions were tested for antibiotic activity against multidrug-resistant $S$. aureus ATCC BAA-44. Fractions 4 and 7 were found to inhibit the tested pathogen at $72.5 \%$ and $82.1 \%$, respectively. There was no significant difference found in the antibiotic activities of Fractions 4 and 7, as shown by $p$ value of 0.4109 using two-tailed test $(p \leq 0.05)$ (Table 4$)$. The remaining GPC fractions were inactive against the tested pathogen.

For high performance liquid chromatography (HPLC) profiling of the GPC fractions, we focused on Fraction 7 because the HPLC chromatogram revealed a single peak at $\lambda_{\max } 254 \mathrm{~nm}$ that eluted at $18.7 \mathrm{~min}$ (Figure 3A) and showed $82.1 \%$ inhibitory against S. aureus ATCC BAA-44 (Figure 3B). The liquid chromatography mass spectrometry-ion trap-time of flight (LCMS-IT-TOF) analysis of this peak showed a compound with mass at $m / z 317.0635[\mathrm{M}+\mathrm{H}]^{+}$and $m / z 315.0368[\mathrm{M}+\mathrm{H}]^{-}$(Figure 3C,D). MS/MS analysis revealed that the compound is the flavonoid isorhamnetin (Figure S5), whose identity was unambiguously confirmed by the fragment ions at $m / z 302\left([(\mathrm{M}+\mathrm{H})-15]^{+}\right)$and $285\left([(\mathrm{M}+\mathrm{H})-(15+17)]^{+}\right)$due to the fragmentation of the methyl at $3^{\prime}$ position and $-\mathrm{OH}$ at 7 position. The mass loss of the $165 \mathrm{~m}$.u. to produce a fragment ion $m / z 153$ showed that the additional methyl was linked to this fragment at $3^{\prime}$ position instead of at 7 position (Figure S5). Further, the MS/MS fragmentation of this bioactive compound matches that of isorhamnetin in the MS/MS Spectrum Match program in METLIN ${ }^{\mathrm{TM}}$ Database [32] (Figure S5). There is a likelihood that the prominent UV peak at $16.7 \mathrm{~min}$ observed in crude extract (Figure 3A) should it corresponds to an analogue of isorhamnetin could provide insight on structure-activity relationship. However, the UV peak at $16.7 \mathrm{~min}$ went to inactive Fraction 5 during fractionation by GPC (Table 4 and Figure S6). The bioactive 
constituents in Fraction 4 as shown by numerous UV peaks at $\lambda_{\max } 254 \mathrm{~nm}$ (Table 4 and Figure S7), warrant further research, which thus constitutes part of our continuing natural products discovery program.

Table 4. Gel Permeation Chromatography (GPC) Purification of SL 01 Honey Crude Extract Showing Eight Major Fractions, Color Profile and Yield and Antibiotic Activity against Multidrug-resistant S. aureus ATCC BAA-44.

\begin{tabular}{cccc}
\hline Sample/Fraction & Visible Color Profile & $\begin{array}{c}\text { Yield from 510.0 mg } \\
\text { SL 01 Honey Crude Extract mg }\end{array}$ & $\begin{array}{c}\text { \% Growth Inhibition against } \\
\text { Multidrug-Resistant } \\
\text { S. aureus ATCC BAA-44 }\end{array}$ \\
\hline Tetracycline $^{\text {a }}$ DMSO $^{\text {b }}$ & - & - & $99.2719 \pm 0.03$ \\
Crude extract $_{1}$ & - & - & no activity \\
2 & colorless & 5.1 & $94.25 \pm 0.24$ \\
3 & red orange & 23.5 & no activity \\
4 & yellow orange & 149.5 & no activity \\
5 & green orange & 219.2 & $72.5 \pm 4.38^{c}$ \\
6 & yellow green & 41.6 & no activity \\
7 & colorless & 39.7 & no activity \\
8 & light yellow & 24.1 & $82.1 \pm 9.50^{c}$ \\
no activity
\end{tabular}

${ }^{a}$ Tetracycline $(0.25 \mathrm{mg} / \mathrm{mL}) ;{ }^{\mathrm{b}} \mathrm{DMSO} ;{ }^{\mathrm{c}}$ Two-tailed $p$ value equals 0.4109 . Honey samples were tested at $5 \mathrm{mg} / \mathrm{mL}$.

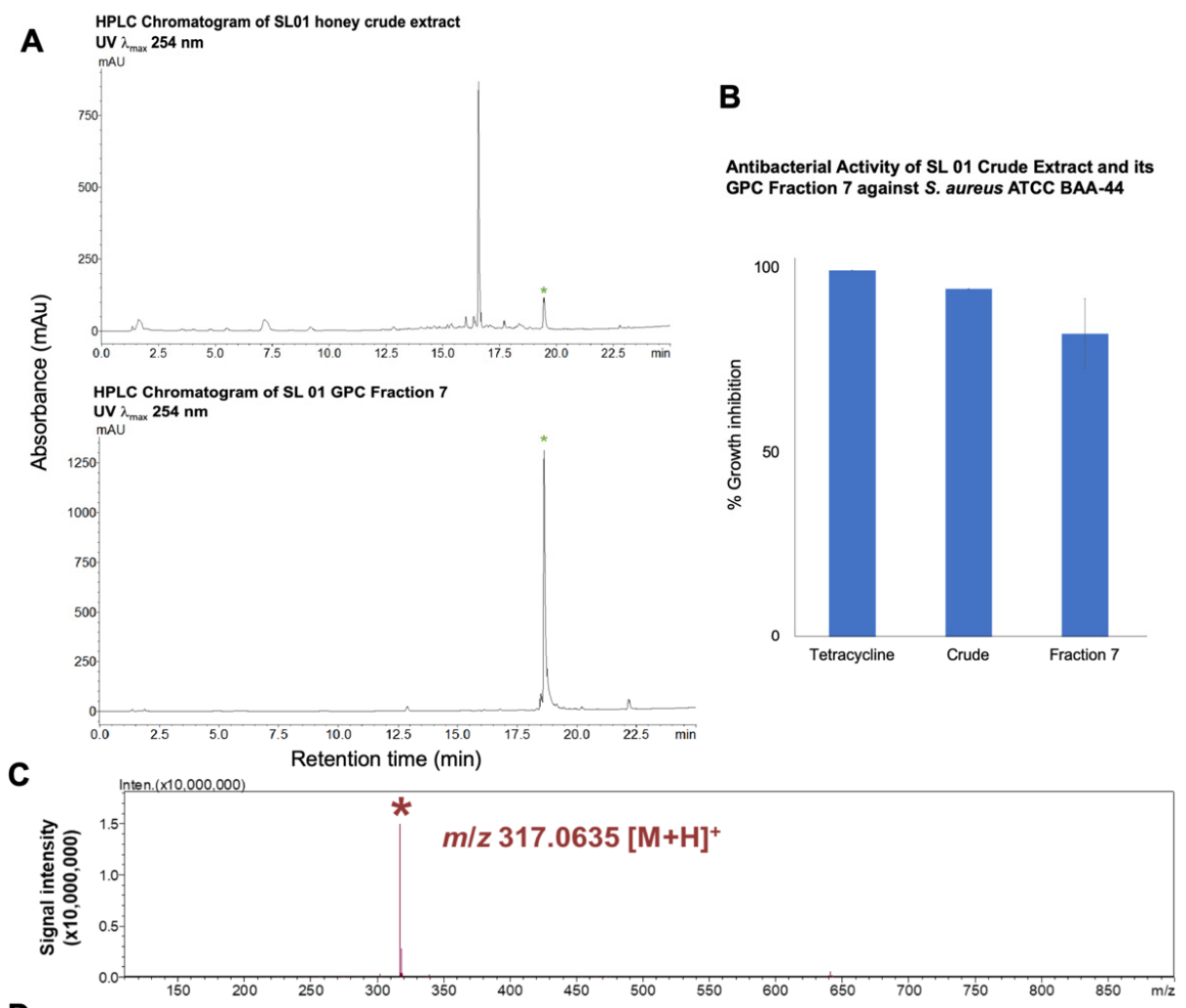

D

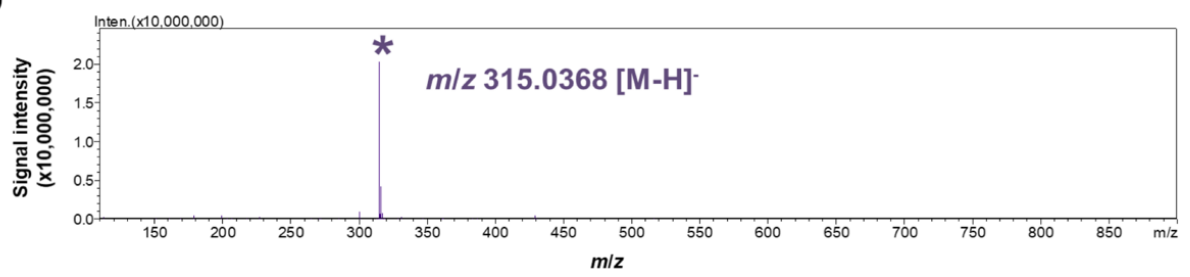

Figure 3. (A) High performance liquid chromatography (HPLC) Chromatogram of SL 01 crude extract and GPC fraction 7 showing a peak at $\lambda_{\max } 254 \mathrm{~nm}$ that eluted at $18.7 \mathrm{~min}$. (B) Antibacterial activities of SL 01 honey crude extract and Fraction 7 against $S$. aureus ATCC BAA- 44 at $5 \mathrm{mg} / \mathrm{mL}$; Tetracycline at $0.25 \mathrm{mg} / \mathrm{mL}$ as positive control. DMSO showed no inhibitory activity towards $S$. aureus ATCC BAA-44. LCMS-IT-TOF analysis of peak at 18.7 min showing a measured mass at (C) $m / z$ $317.0635[\mathrm{M}+\mathrm{H}]^{+}$and (D) $m / z 315.0368[\mathrm{M}-\mathrm{H}]^{-}$. 


\section{Discussion}

Herein we report that secondary metabolites present in honey possess antibacterial and antioxidant activities. Our findings revealed that the selected Philippine honey extracts in this study showed in vitro antibacterial activities against Staphylococcal pathogens. The antibacterial activity, however, varied with the honey type. It was shown that honey extract produced by the $A$. mellifera bee species exhibits weak antibiotic activities, while the SL 01 honey extract produced by $T$. biroi exhibits moderate to high antibacterial activity against all Staphylococcal pathogens tested, including the multidrug-resistant S. aureus ATCC BAA44. Nonetheless, it is evident that $T$. biroi honey extract possesses higher and broader antibacterial activities compared to A. mellifera honey extracts. This finding corroborates the report that the stingless bee honey (SBH) demonstrates superior antibacterial activities when compared to European bee honey (EBH) produced by Apis spp [33-35].

Honey has several well-known characteristics that are generally accepted as contributing factors in the overall antimicrobial activity, which include low $\mathrm{pH}$, an osmotic effect, hydrogen peroxide production, and phytochemical factors [1,2]. In this study, T. biroi (SL 01) honey extract remained active against five Staphylococcal pathogens after the removal of oligosaccharides and moisture, thus, indicating that the antibacterial component is non-volatile and non-peroxidase in contrast to other studies in honey whereby antibacterial activity is attributed to the presence of enzymes such as catalase and peroxidase $[1,2,6]$. There were several UV peaks at $\lambda_{\max } 254 \mathrm{~nm}$ that may contribute to the antibiotic activity of SL 01 extract Fraction 7. Nevertheless, the isorhamnetin (3-methylquercetin), a plant flavonoid that we detected in Fraction 7, was the major UV peak $\left(\lambda_{\max } 254 \mathrm{~nm}\right)$ that plausibly contributed to the nonperoxide antibacterial activity of the T. biroi honey. A report on the mechanism of action of methylated flavonoids such as isorhamnetin showed that it targets bacterial cell membrane by increasing permeability, leading to cessation of ATP synthesis capacity, membrane transport, and motility [36]. It has been demonstrated that isorhamnetin inhibits the growth of $S$. aureus by down-regulating its RNAIII expression and inhibiting the alpha-hemolysin (Hla) transcription [37]. This metabolite, together with other flavonoids, may exhibit its antibacterial activity by cell lysis and disruption of the cytoplasmic membrane upon permeability [37-39].

The antibacterial activities of Manuka honey crude extract in this study do not agree with the reported potent bioactivity of methylglyoxal (MGO) [31,40]. Perhaps the solidphase extraction and in vacuo drying processes $\left(35-40^{\circ} \mathrm{C}\right)$ removed the volatile MGO. Nonetheless, our findings concur with previous reports that MGO is not solely responsible for Manuka honey's antimicrobial activity [30,41,42].

We demonstrated that SL 01 honey extract possesses the highest antioxidant activity among the selected Philippine honey extract tested, and whose activity attribute to its high phenolic and flavonoid contents. This finding corroborates with a recent study on $T$. biroi honey, which claims that phenolic acids and flavonoids are responsible for the wellestablished antioxidant activity of stingless bee honey [25]. There are reports indicating that phenolics and flavonoids in honey are greatly influenced by the floral source where the bee species forage for food $[8,14,43]$. In this preliminary study, the correlation of antibiotic and antioxidant activities to the botanical and entomological origins of honey is not clear because of narrow set of samples and lack of melissopalynological analysis information. Nonetheless, the results of the study are promising, as we have demonstrated the potential antibacterial and antioxidant activities of Philippine honeys derived from A. mellifera and stingless bee T. biroi. For some honey extracts with high phenolic content such as NM 02 , NM 05, and SL 05, the amount of phenolic content was not directly correlated to its antioxidant activity. This observation could be due to some other constituents that suppress its radical scavenging activity, as the examined samples were from crude extracts.

The clustering analysis suggests that bioactivities (antibiotic and antioxidant) correlate directly to the total phenolic content and flavonoid contents as demonstrated by SL 01 honey extract produced by a stingless bee T. biroi, followed by the Manuka honey extracts in cluster 2. It is clear that the well-defined clustering as displayed in the dendrogram is 
consistent with the direct correlation between bioactivities and phenolic and flavonoid contents, i.e., honey extracts with a low amount of phenols and flavonoids, consequently, showed weak antibacterial activity.

In this work, the T. biroi honey crude extract showed the highest content of phenolics and flavonoids, with isorhamnetin as one of its antibiotic components. Isorhamnetin is known to be present in various plants such as mangoes and bananas [44-46], which suggests the possible origin of isorhamnetin in T. biroi honey, since the foraging area of the bee hives was surrounded by coconut, banana, and mangoes trees. Interestingly, there were also honeys in this study produced by A. mellifera (WV 02, SEM 01, and SL 04) that foraged in mangoes and bananas, yet showed minimal antibiotic activities. Although there are limited studies on the foraging mechanisms of T. biroi, it was suggested that its smaller body size allows itself to gather food from the different parts of the floral source, resulting in high flavonoids and phenolic acid content [47]. Another plausible explanation for the source of isorhamnetin found in T. biroi honey is the cerumen, also known as stingless bee propolis [48]. The cerumen is a mixture of wax and plant resins that are used as material in building the stingless bee nest. Plant resins are rich source of flavonoids and are well-known for their potent antimicrobial properties [49]. Unlike A. mellifera that preserves honey by a dehydration technique while being stored in the honeycomb, the stingless bee (e.g., T. biroi) relies on intense fermentation by symbiont microbes and by aging inside the cerumen pot to preserve the honey [50]. While aging, the aromas from the cerumen are incorporated into honey, giving its intense aroma compared to A. mellifera honey. It has been reported that cerumen extracts have anti-inflammatory and antimicrobial properties $[49,51,52]$ and it is possible that the antibiotics and antioxidants from the cerumen are integrated in the honey during aging process [50]. Report showed that a total of 100 compounds have been identified from stingless bee propolis from 2000 to 2019 by groups in Brazil, South Asia and Australia [48]. To note, isorhamnetin was isolated from the nest of stingless bee T. spinipes collected in Fortaleza, state of Ceará, Northeast of Brazil [53]. Collectively, the findings of this study on the anti-staphylococcal activity of T. biroi honey extract and reports on the biological potential of stingless bee honey from Brazil [49,54], South Asia $[25,26,47,55,56]$, and Australia $[48,51,57]$ underscore the beneficial properties and nutritional value of stingless bee honey.

\section{Materials and Methods}

\subsection{Honey Samples}

A total of 15 raw honey samples produced by A. mellifera ( 14 samples) and stingless bee T. biroi, (1 sample) were collected from different apiaries in the Philippines on September to December 2016. All honey samples were obtained from a local bee farm. In lieu of melissopalynological analysis to determine the floral and botanical origins of honey samples, the identification of botanical origins was performed based on the geographical foraging area and floral availability where bee hives were located. Only one T. biroi honey was collected during that period because of limited production. For A. mellifera honey samples, two were collected from Northern Luzon (NL), five were from Southern Luzon (SL), two were from Western Visayas (WV), one from Southeastern Mindanao (SEM), and five from Northern Mindanao (nm) (Table 1 and Figure S1). Two types of Manuka honey: Comvita $^{\mathrm{TM}}$ (UMF 15), and Manuka Health ${ }^{\mathrm{TM}}$ (MGO 550) were used as references due to their standardized methylglyoxal (MGO) content that was claimed to be antibacterial.

\subsection{Reagents and Standards}

The Amberlite ${ }^{\mathrm{TM}} \mathrm{XAD}-16 \mathrm{~N}$ resin, tetracycline, 2,2-diphenyl-1-picrylhydrazyl (DPPH), ascorbic acid, and quercetin ( $\geq 95 \%$ ) were obtained from Sigma-Aldrich (St. Louis, MO, USA). The gallic acid (99.3\%) was obtained from ChromaDex (Los Angeles, CA, USA). Acetonitrile, methanol, ethyl acetate, water, and formic acid (LC-MS grade) were also purchased from Sigma-Aldrich (St. Louis, MO, USA). 


\subsection{Metabolite Extraction}

Solid Phase Extraction (SPE) method was utilized to extract the secondary metabolite contents of honey [58]. Briefly, $25 \mathrm{~g}$ of honey samples were dissolved in $75 \mathrm{~mL}$ acid water (adjusted to $\mathrm{pH}$ 2.0). The solution was treated with $37.5 \mathrm{~g}$ Amberlite $^{\mathrm{TM}} \mathrm{XAD}-16 \mathrm{~N}$ resin $(100 \mu \mathrm{m})$ and gently stirred for $30 \mathrm{~min}$ to allow adsorption of metabolites. After stirring, the resin was washed with $2 \mathrm{~L}$ acid water followed by $1 \mathrm{~L}$ distilled water. Subsequently, the resin was washed with methanol $(750 \mathrm{~mL})$ and ethyl acetate $(750 \mathrm{~mL})$ to extract the adsorbed metabolites. This step was repeated three to four times until the resin returned to its original white appearance. The combined methanol and ethyl acetate extracts (9-10 g, $36-40 \%$ yield) were concentrated in vacuo at 35 to $40{ }^{\circ} \mathrm{C}$, lyophilized, and stored at $-80{ }^{\circ} \mathrm{C}$ until used for in vitro antibacterial and antioxidant assays and chemical profiling.

\subsection{Target Organisms for Antibacterial Testing}

The target bacterial pathogens used in this study were Staphylococcus aureus ATCC 25923, S. aureus ATCC BAA-44 (multidrug-resistant), S. aureus ATCC 6538, S. saprophyticus clinical isolate, and S. epidermidis clinical isolate. These test organisms were grown and maintained at $37^{\circ} \mathrm{C}$ in tryptic soy agar for no more than $24 \mathrm{~h}$ until they were used for antibacterial assay.

\subsection{Agar Well Diffusion for Antibacterial Assay}

The honey extracts obtained from SPE were tested for antibacterial activity using the agar well diffusion method. Briefly, ten $\mathrm{mL}$ of bacterial cell suspension was adjusted to obtain an optical density (OD) of $1 \times 10^{6} \mathrm{CFU} / \mathrm{mL}$ and mixed thoroughly with $40 \mathrm{~mL}$ of $1.5 \%$ Mueller-Hinton Agar (MHA) at $40^{\circ} \mathrm{C}$. MHA inoculated with bacterial cells was poured into a $150 \mathrm{~mm}$ Petri dish and allowed to solidify. After solidification, agar wells were made using sterile borer to make a $6 \mathrm{~mm}$ well. Honey extracts in dimethyl sulfoxide (DMSO) were prepared at $200 \mathrm{mg} / \mathrm{mL}$ stock solution. Fifty $\mu \mathrm{L}$ of honey extracts was dispensed into each well corresponding to a treatment of $10 \mathrm{mg}$ sample per well. Fifty $\mu \mathrm{L}$ of tetracycline ( $5 \mathrm{mg} / \mathrm{mL}$ in DMSO) and $50 \mu \mathrm{L}$ DMSO were dispensed into separate wells as positive and negative controls, respectively. All test pathogens in this study were not sensitive to DMSO (Table 2). The plates were incubated at $37^{\circ} \mathrm{C}$ for $18 \mathrm{~h}$ followed by measurement of the zone of inhibition (ZOI, $\mathrm{mm}$ ) after subtracting the $6 \mathrm{~mm}$ diameter of the well. All tests were performed in duplicate.

\subsection{Antioxidant Assay Using 2,2-Diphenyl-1-Picrylhydrazyl (DPPH)}

To provide a preliminary screening for the antioxidant activity of the honey extracts, the radical scavenging activity was assessed using the free radical DPPH assay, as described previously [59] with few modifications. Twenty $\mu \mathrm{L}$ of each honey extracts $(50 \mathrm{mg} / \mathrm{mL}$ in DMSO, pH 3.5 to 4.5) and $180 \mu \mathrm{L}$ of DPPH (Sigma Aldrich, St. Louis, MO, USA) solution (300 $\mu \mathrm{M}$ in methanol) were dispensed in wells of a 96-well plate. Twenty $\mu \mathrm{L}$ of DMSO with $180 \mu \mathrm{L}$ DPPH solution was used as the negative control, while ascorbic acid (Sigma Aldrich, (St. Louis, MO, USA) $(10 \mathrm{mg} / \mathrm{mL})$ was used as a positive control. The plate was incubated in the dark at room temperature for $30 \mathrm{~min}$ followed by the measurement of absorbance at $570 \mathrm{~nm}$ using the microplate plate reader (Multiskan FC, Thermo Scientific, Torrance, CA, USA). The assay was performed in triplicates. The $\% \mathrm{DPPH}$ radical scavenging activity of honey extracts was determined using the following formula:

\subsection{Quantification of Flavonoids}

The flavonoid content of honey was determined through the formation of aluminumflavonoid complexes, with some modifications [59]. An aliquot of $\mathrm{AlCl}_{3}$ solution $(4 \mu \mathrm{L}, 10 \%$ $w / v)$ was added to honey extract aqueous solution $(20 \mu \mathrm{L}, 50 \mathrm{mg} / \mathrm{mL})$ and subsequently treated with $\mathrm{H}_{2} \mathrm{O}(112 \mu \mathrm{L}), 60 \mu \mathrm{L}$ methanol and $1 \mathrm{M} \mathrm{CH}_{3} \mathrm{COONa}(4 \mu \mathrm{L})$. Quercetin $(\geq 95 \%$, 
Sigma Aldrich, St. Louis, MO, USA) was used as standard at a concentration range of 0 to $100 \mu \mathrm{g} / \mathrm{mL}$ to establish the calibration curve. The mixture was vigorously shaken and incubated at $24{ }^{\circ} \mathrm{C}$ in a microplate reader (BMG Labtech, Offenburg, Germany) for $10 \mathrm{~min}$. The absorbance was read at $415 \mathrm{~nm}$. The assay was performed in triplicates.

\subsection{Determination of Total Phenolic Content}

The Folin-Ciocalteu (F-C) assay while traditionally used for total phenolic content (TPC) in plant food extracts may produce inaccurate estimations of TPC values due to the presence of reducing interferants such as ascorbic acid [60]. In order to mitigate this limitation, we utilized a more novel method using chemometrics (i.e., partial least squares) and FTIR. PLS offers the advantages of simplicity and being able to quantify analytes of interest from a complex matrix [61-63]. The total phenolics content (TPC) of honey extract solution $(10 \mu \mathrm{L}, 500 \mathrm{mg} / \mathrm{mL}$ in methanol) was quantified by Attenuated Total ReflectanceFourier Transform Infrared Spectroscopy (ATR-FTIR) [64]. FTIR spectra were recorded at room temperature $\left(22^{\circ} \mathrm{C}\right)$ using IRAffinity-1S spectrometer (Shimadzu, Kyoto, Japan) scanning through the frequency range of 4000 to $700 \mathrm{~cm}^{-1}$ at a resolution of $2 \mathrm{~cm}^{-1}$. The final IR spectrum of each honey extract was an average of 128 scans with two spectra taken per aliquot. The experiment was performed in triplicates.

The IR spectra of honey extracts averaged and were processed using the R software (R Development Core Team, Vienna, Austria) for further analysis. Savitkzy Golay was performed, with a three-point filter and wavelet transform scale of three to enhance the resolution of spectral features and to minimize problems from baseline shifts. Partial least-squares regression (PLSR) with three components was employed for the quantitative analysis. A total of seven spectra of gallic acid (99.3\%, Chromadex, Los Angeles, CA, USA) were used to establish the calibration model. A leave-one-out cross validation was performed to evaluate the accuracy of the model by removing one standard from the data set at a time and applying a calibration to the remaining standards (Figures S2-S4).

\subsection{Purification and Isolation of Antibiotic Compound from Philippine Honey}

The crude honey extract obtained was purified by gel permeation chromatography (GPC). Crude extract $(510.0 \mathrm{mg}$ ) was dissolved in $1.0 \mathrm{~mL}$ methanol and loaded to a $3.3 \mathrm{~cm} \times 35 \mathrm{~cm}$ column Sephadex ${ }^{\circledR}$ LH-20 (bead size: $25-100 \mu \mathrm{m}$, bed volume: $307.9075 \mathrm{~cm}^{3}$, linear flow rate: $9.82 \mathrm{~cm} / \mathrm{h}$ ). The column was eluted with methanol and 69 of $7 \mathrm{~mL}$ fractions were collected. We attempted to pool the eluates according to TLC profile, however the compounds present in the eluate did not resolve well in silica plate. Consequently, eluates were pooled into 8 major fractions based on their visible color profiles, the pooled fractions were concentrated in vacuo, and freeze dried for subsequent assays and chemical profiling analyses.

\subsection{Chemical Profiling of Bioactive Honey GPC Fraction Using High Performance Liquid Chromatography (HPLC)-Diode-Array Detector (DAD)}

The GPC fractions were profiled using HPLC (LC-20AD Prominence and PDA SPDM20A Prominence, Shimadzu, Kyoto, Japan). Briefly, GPC fractions at $10 \mathrm{mg} / \mathrm{mL}\left(\mathrm{MeOH}: \mathrm{H}_{2} \mathrm{O}\right.$, 1:1) were filtered using a $0.2 \mu \mathrm{m}$ filter syringe. Twenty $\mu \mathrm{L}$ of the filtered GPC solution was injected in HPLC. The purification was carried out on a reversed phase column (Phenomenex Kinetex $\mathrm{C}_{8}$ column, $2.6 \mu \mathrm{m}, 100 \times 4.60 \mathrm{~mm}$ ) using a low-pressure gradient elution solvent system (solvent A: water with $0.1 \%$ TFA, solvent B: methanol with $0.1 \%$ TFA) at a flow rate of $0.8 \mathrm{~mL} / \mathrm{min}$. The gradient started with $95 \%$ solvent $\mathrm{A}$ at 0.01 to $5 \mathrm{~min}$, $60 \%$ solvent $A$ at $10 \mathrm{~min}, 30 \%$ solvent $A$ at $15 \mathrm{~min}, 0 \%$ solvent $A$ at 20 to 33 min, back to $95 \%$ solvent $A$ at $35 \mathrm{~min}$. The UV peaks $\left(\lambda_{\max } 254 \mathrm{~nm}\right)$ of the GFC fraction with the highest antibacterial activity against multidrug-resistant $S$. aureus ATCC BAA-44 were collected for LCMS-IT-TOF and MS/MS analyses (Table 4). 


\subsection{Microbroth Susceptibility Assay of GPC Fractions against S. aureus ATCC BAA-44}

Microbroth assay was performed to demonstrate the antibacterial activity of crude extract and its corresponding GPC fractions against the multidrug-resistant $S$. aureus ATCC BAA-44 strain [65]. Briefly, a bacterial cell suspension adjusted to $1.0 \times 10^{6} \mathrm{cfu} / \mathrm{mL}$ in tryptic soy broth medium was prepared. Five $\mu \mathrm{L}$ of $200 \mathrm{mg} / \mathrm{mL}$ honey extract stock solution as well as the GPC fraction, $5 \mu \mathrm{L}$ of $10 \mathrm{mg} / \mathrm{mL}$ tetracycline as the positive control, and $5 \mu \mathrm{L}$ of DMSO as the negative control were placed in different wells (96-well plate) in triplicates. Afterwards, $195 \mu \mathrm{L}$ of bacterial cell suspension was added to each well. Finally, $200 \mu \mathrm{L}$ of tryptic soy broth was dispensed in wells that served as blanks. The plate was incubated at $37^{\circ} \mathrm{C}$ and the optical density was measured at $620 \mathrm{~nm}$ after $18-24 \mathrm{~h}$ incubation using a microplate reader (Multiskan FC, Thermo Scientific, USA). All test pathogens in this study were not sensitive to DMSO (Table 2). The assay was performed in triplicates. Percent inhibition was measured relative to the untreated tested bacteria.

\subsection{Determination of Minimum Inhibitory Concentration (MIC)}

The minimum inhibitory concentration (MIC) of SL 01 honey crude extract against multidrug-resistant $S$. aureus ATCC BAA- 44 was determined using broth microdilution method as previously described by Dalisay et al. (2013) [65]. Briefly, 2-fold serial dilutions of honey crude extracts in DMSO $(200 \mathrm{mg} / \mathrm{mL})$ stock solution were prepared in 96-well microtiter to yield a final test concentration range of 5000 to $9.8 \mu \mathrm{g} / \mathrm{mL}$. Bacterial inoculum was prepared from $24 \mathrm{~h}$ culture on tryptic soy agar at $37^{\circ} \mathrm{C}$. The inoculum was diluted into Tryptic Soy broth to yield a final inoculum with an optical density of $1.0 \times 10^{6} \mathrm{cfu} / \mathrm{mL}$. The microdilution wells, which contained $5 \mu \mathrm{L}$ of the serially diluted extracts, were inoculated with $195 \mu \mathrm{L}$ of the resulting bacterial suspension. Tetracycline and DMSO were used as positive and negative controls, respectively. The inoculated plates were incubated at $37^{\circ} \mathrm{C}$ for $18 \mathrm{~h}$. Determinations were carried out in triplicates. The inhibition of growth was determined by measuring the OD at $600 \mathrm{~nm}$. The MIC end point was defined as the lowest concentration with $90 \%$ growth inhibition.

\subsection{Ultra High Pressure Liquid Chromatography Mass Spectrometry (UPLCMS) and MS/MS} Analysis of Bioactive GPC Fraction

High-resolution MS and MS/MS experiment of the HPLC UV peak ( $\left.\lambda_{\max } 254 \mathrm{~nm}\right)$ of bioactive GPC (see Section 2.4) fraction were acquired using a Shimadzu LCMS-IT-TOF equipped with a Prominence HPLC system (SIL-20A HT autosampler, LC-20AD pump system, SDP-M20A diode array detector) with reversed-phase column (Phenomenex Luna $\mathrm{C}_{8}$ column, $5 \mu \mathrm{m}, 150 \times 2 \mathrm{~mm}$ ) and a gradient of $\mathrm{MeOH}$ in $\mathrm{H}_{2} \mathrm{O}$ containing $0.01 \%$ formic acid as eluent $(0-100 \%$ over $30 \mathrm{~min})$ at a flow rate $0.5 \mathrm{~mL} / \mathrm{min}$. The sample load was $20 \mu \mathrm{L}$ with a concentration of $2.5 \mathrm{mg} / \mathrm{mL}$ ( $50: 50 \mathrm{MeOH}: \mathrm{H}_{2} \mathrm{O}$ ). The MS analysis used the following conditions: block temperature $-300{ }^{\circ} \mathrm{C}$, DL temperature $-250{ }^{\circ} \mathrm{C}$, nebulizing gas flow rate $-1.5 \mathrm{~L} / \mathrm{min}$, drying gas flow rate- $15.0 \mathrm{~L} / \mathrm{min}$, mass range- $110-900 \mathrm{amu}$ (positive and negative mode), event time- $-100 \mathrm{~ms}$, and the ion accumulation time- $-30 \mathrm{~ms}$.

The MS/MS experiment was performed in 50\% collision energy. The identified antibacterial compound was set as the precursor ion and fragments with mass range of $m / z$ $50-900$ in positive mode were recorded. The identity of the metabolites was obtained after comparison with the databases such as METLIN ${ }^{\mathrm{TM}}$, AntiBase, PubChem, and ChemSpider. Fragmentation of the metabolite of interest was also generated for confirmation.

\subsection{Data Processing and Statistical Analysis}

The antibacterial and antioxidant activities were expressed as mean \pm standard error. Paired $t$-test analysis was performed to determine significance in the mean values of antibacterial and antioxidant activities. The heat map that shows the antibacterial activity, antioxidant activity, flavonoid content, and phenolic content of Philippine honey and Manuka honey was constructed using TreeView 3.0 (http://jtreeview.sourceforge.net/, accessed on 17 January 2021) [66]. Data for each test were normalized and relative val- 
ues were subjected to data correlation using City Block Distance with complete linkage calculation between groups.

\section{Conclusions}

The extracts from honey produced by the stingless bee T. biroi exhibited antibacterial activity against Staphylococcal pathogens with strong activity against the multidrug-resistant S. aureus and demonstrates high antioxidant activity compared to A. mellifera honey extracts. The flavonoids and phenolic compounds found in Philippine honey extracts have a direct link to the in vitro antibacterial activities as well as antioxidant activities. This is the first antibiotic activity screening of Philippine honey extracts produced by A. mellifera and T. biroi against Staphylococcal pathogens and antioxidant evaluation. This preliminary work showed isorhamnetin as one of the antibiotic components found in T. biroi honey extract. The results of this preliminary study increase our knowledge of Philippine honey as a potential nutraceutical agent with therapeutic benefits against Staphylococcal pathogens. Future studies using a broader set of Philippine T. biroi honey samples from various geographical areas, coupled with melissopalynological analysis for identification of the botanical origins, are needed to evaluate their therapeutic potential. Moreover, chemical profiling and metabolomics of the samples should be performed to investigate the metabolite composition that may serve as parameters to reveal biological activities, chemodiversity, as well as the geographical, entomological, and plant origins of Philippine honeys with therapeutic nutraceutical potential.

Supplementary Materials: The following are available online. Figure S1: Philippine Map annotated with collection sites of honey samples. Figure S2: FTIR spectral features of honey crude extracts used for the quantification of phenolic acids in honey extracts. The sample FTIR spectrum shown was SL 01 honey. Figure S3: The root mean square error of prediction (RMSEP) of the partial least squares regression (PLSR) model with respect to the number of components. Savitzky Golay was applied for spectral smoothing of all honey samples used in this study. Three components were chosen with RMSEP $=0.08611$ and R2 $=0.9926$. Savitkzy Golay was performed, with a three-point filter and wavelet transform scale of three, to enhance the resolution of spectral features and to minimize problems from baseline shifts. Figure S4: The partial least squares (PLS) train model of three components used for the quantification of total phenolic acid content in honey samples in this study. The line graph is the total of seven spectra of gallic acid (99.3\%, ChromaDex, Los Angeles, CA, USA) were used to establish the calibration model. A leave-one-out cross validation was performed to evaluate the prediction power of the model. Figure S5: MS/MS fragmentation of $m / z 317.0635$ $[\mathrm{M}+\mathrm{H}]^{+}$using $50 \%$ collision energy and detected using LCMS-IT-TOF, $m / z$ range from 50 to 900 in positive mode. * $m / z 318.0670$ and $m / z 319.06$ (a very small peak) are residue isotopic peaks of precursor ion $m / z 317.0635[\mathrm{M}+\mathrm{H}]^{+}$. Figure S6: HPLC Chromatogram of SL 01 crude extract and GPC Fraction 5 showing peaks at $\lambda_{\max } 254 \mathrm{~nm}$. Figure S7: HPLC Chromatogram of SL 01 crude extract and GPC Fraction 4 showing peaks at $\lambda_{\max } 254 \mathrm{~nm}$.

Author Contributions: Conceptualization, J.P.S. and D.S.D.; methodology, J.P.S., J.V.N.S., G.G.D., Z.S., Z.Q.Z. and D.S.D.; software, A.F.L.S., A.D.G.T., J.P.S., J.V.N.S., G.G.D., Z.S., Z.Q.Z. and D.S.D.; validation, A.F.L.S., A.D.G.T., Z.M.V., C.F.B., J.V.N.S., G.G.D., Z.S., Z.Q.Z., J.P.S. and D.S.D.; formal analysis, A.F.L.S., A.D.G.T., Z.M.V., C.F.B., J.V.N.S., G.G.D., Z.S., Z.Q.Z., J.P.S. and D.S.D.; investigation, A.F.L.S., A.D.G.T., Z.M.V., C.F.B., J.V.N.S., G.G.D., Z.S., Z.Q.Z., J.P.S. and D.S.D.; resources, J.V.N.S., G.G.D., Z.S., Z.Q.Z., J.P.S. and D.S.D.; data curation, A.F.L.S., A.D.G.T., J.V.N.S., G.G.D., Z.S., Z.Q.Z., J.P.S. and D.S.D.; writing-original draft preparation, A.F.L.S., G.G.D., J.P.S. and D.S.D.; writing - review and editing, A.F.L.S., A.D.G.T., Z.M.V., C.F.B., J.V.N.S., G.G.D., Z.S., Z.Q.Z., J.P.S., and D.S.D.; visualization, A.F.L.S., A.D.G.T., Z.M.V., C.F.B., J.V.N.S., G.G.D., Z.S., Z.Q.Z., J.P.S. and D.S.D.; supervision, J.V.N.S., G.G.D., Z.Q.Z., J.P.S. and D.S.D.; project administration, J.P.S. and D.S.D.; funding acquisition, D.S.D. All authors have read and agreed to the published version of the manuscript.

Funding: This work was funded by the United States Agency for International Development (USAID) Philippines through the Science, Technology, Research, and Innovation for Development (STRIDE) Program implemented by RTI International under grant agreement number 0213997-G-2017-002-00. 
Institutional Review Board Statement: Not applicable.

Informed Consent Statement: Not applicable.

Data Availability Statement: The data presented in this study are available in the Supplementary Materials.

Acknowledgments: The authors Dalisay, Saludes, and Dumancas wish to thank the Balik Scientist Program of the Department of Science and Technology (DOST), Philippines through the Philippine Council for Health Research and Development (PCHRD) for the opportunity to serve the Filipino community through science, technology, and innovation. The Balik (Filipino word for Returning) Scientist Program (BSP) seeks highly-trained Filipino scientists, technologists, experts, and professionals residing abroad to return to the Philippines and transfer their expertise to the local community for the acceleration of scientific, agro-industrial and economic development of the country. We wish to thank Shimadzu Philippines Corporation for the technical assistance.

Conflicts of Interest: Authors Zenith Villorente, Cathrina Bagarinao, and Jan Vincent N. Sollesta were employed by Maridan Industries, Inc., Jaro, Iloilo City, Philippines. Authors Zhe Sun, Zhao Qi Zhan were employed by Shimadzu Asia Pacific (SAP), Singapore Science Park I, Singapore. All other authors declare no competing interests. Also, the authors declare that the research was conducted in the absence of any commercial or financial relationships that could be construed as a potential conflict of interest.

Sample Availability: Not applicable.

\section{References}

1. Miguel, M.G.; Antunes, M.D.; Faleiro, M.L. Honey as a complementary medicine. Integr. Med. Insights. 2017, 12, 1178633717702869. [CrossRef] [PubMed]

2. Combarros-Fuertes, P.; Fresno, J.M.; Estevinho, M.M.; Sousa-Pimenta, M.; Tornadijo, M.E.; Estevinho, L.M. Honey: Another alternative in the fight against antibiotic-resistant bacteria? Antibiotics 2020, 9, 774. [CrossRef] [PubMed]

3. Brown, H.L.; Metters, G.; Hitchings, M.D.; Wilkinson, T.S.; Sousa, L.; Cooper, J.; Dance, H.; Atterbury, R.J.; Jenkins, R. Antibacterial and antivirulence activity of manuka honey against genetically diverse Staphylococcus pseudintermedius Strains. Appl. Environ. Microbiol. 2020, 86. [CrossRef] [PubMed]

4. Amalia, E.; Diantini, A.; Subarnas, A. Water-soluble propolis and bee pollen of Trigona spp. from South Sulawesi Indonesia induce apoptosis in the human breast cancer MCF-7 cell line. Oncol. Lett. 2020, 20, 274. [CrossRef] [PubMed]

5. Martinotti, S.; Ranzato, E. Honey, wound repair and regenerative medicine. J. Funct. Biomater. 2018, 9, 34. [CrossRef] [PubMed]

6. Ahmed, S.; Sulaiman, S.A.; Baig, A.A.; Ibrahim, M.; Liaqat, S.; Fatima, S.; Jabeen, S.; Shamim, N.; Othman, N.H. Honey as a potential natural antioxidant medicine: An insight into its molecular mechanisms of action. Oxid. Med. Cell Longev. 2018, 2018, 8367846. [CrossRef] [PubMed]

7. Bucekova, M.; Jardekova, L.; Juricova, V.; Bugarova, V.; Di Marco, G.; Gismondi, A.; Leonardi, D.; Farkasovska, J.; Godocikova, J.; Laho, M.; et al. Antibacterial activity of different blossom honeys: New findings. Molecules 2019, 24, 1573. [CrossRef] [PubMed]

8. Barbieri, D.; Gabriele, M.; Summa, M.; Colosimo, R.; Leonardi, D.; Domenici, V.; Pucci, L. Antioxidant, nutraceutical properties, and fluorescence spectral profiles of bee pollen samples from different botanical origins. Antioxidants 2020, 9, 1001. [CrossRef] [PubMed]

9. Cridland, J.M.; Tsutsui, N.D.; Ramírez, S.R. The complex demographic history and evolutionary origin of the western honey bee, Apis Mellifera. Genome Biol. Evol. 2017, 9, 457-472. [CrossRef] [PubMed]

10. Döke, M.A.; McGrady, C.M.; Otieno, M.; Grozinger, C.M.; Frazier, M. Colony size, rather than geographic origin of stocks, predicts overwintering success in honey bees (Hymenoptera: Apidae) in the Northeastern United States. J. Econ. Entomol. 2019, 112, 525-533. [CrossRef]

11. Homrani, M.; Escuredo, O.; Rodríguez-Flores, M.S.; Fatiha, D.; Mohammed, B.; Homrani, A.; Seijo, M.C. Botanical origin, pollen profile, and physicochemical properties of Algerian honey from different bioclimatic areas. Foods 2020, 9, 938. [CrossRef] [PubMed]

12. Carabetta, S.; Di Sanzo, R.; Campone, L.; Fuda, S.; Rastrelli, L.; Russo, M. High-Performance anion exchange chromatography with pulsed amperometric detection (HPAEC-PAD) and chemometrics for geographical and floral authentication of honeys from southern Italy (Calabria region). Foods 2020, 9, 1625. [CrossRef] [PubMed]

13. Zieliński, L.; Deja, S.; Jasicka-Misiak, I.; Kafarski, P. Chemometrics as a tool of origin determination of Polish monofloral and multifloral honeys. J. Agric. Food Chem. 2014, 62, 2973-2981. [CrossRef] [PubMed]

14. Wang, J.; Li, Q.X. Chemical composition, characterization, and differentiation of honey botanical and geographical origins. Adv. Food Nutr. Res. 2011, 62, 89-137. [PubMed] 
15. Ciulu, M.; Spano, N.; Pilo, M.I.; Sanna, G. Recent advances in the analysis of phenolic compounds in unifloral honeys. Molecules 2016, 21, 451. [CrossRef] [PubMed]

16. Sateriale, D.; Facchiano, S.; Colicchio, R.; Pagliuca, C.; Varricchio, E.; Paolucci, M.; Volpe, M.G.; Salvatore, P.; Pagliarulo, C. Synergy of polyphenolic extracts from honey, myrtle and pomegranate against oral pathogens, S. mutans and $R$. dentocariosa. Front. Microbiol. 2020, 11, 1465. [CrossRef]

17. Pauliuc, D.; Dranca, F.; Oroian, M. Antioxidant activity, total phenolic content, individual phenolics and physicochemical parameters suitability for Romanian honey authentication. Foods 2020, 9, 306. [CrossRef]

18. Zothanpuia; Passari, A.K.; Gupta, V.K.; Singh, B.P. Detection of antibiotic-resistant bacteria endowed with antimicrobial activity from a freshwater lake and their phylogenetic affiliation. PeerJ 2016, 4, e2103. [CrossRef]

19. Kuś, P.M. Honey as source of nitrogen compounds: Aromatic amino acids, free nucleosides and their derivatives. Molecules 2020, 25, 847. [CrossRef] [PubMed]

20. Zhao, H.; Cheng, N.; Wang, Q.; Zhou, W.; Liu, C.; Liu, X.; Chen, S.; Fan, D.; Cao, W. Effects of honey-extracted polyphenols on serum antioxidant capacity and metabolic phenotype in rats. Food Funct. 2019, 10, 2347-2358. [CrossRef] [PubMed]

21. Al-Mamary, M.; Al-Meeri, A.; Al-Habori, M. Antioxidant activities and total phenolics of different types of honey. Nutr. Res. 2002, 22, 1041-1047. [CrossRef]

22. Stephens, J.M.; Schlothauer, R.C.; Morris, B.D.; Yang, D.; Fearnley, L.; Greenwood, D.R.; Loomes, K.M. Phenolic compounds and methylglyoxal in some New Zealand manuka and kanuka honeys. Food Chem. 2010, 120, 78-86. [CrossRef]

23. Wang, X.; Sankarapandian, K.; Cheng, Y.; Woo, S.O.; Kwon, H.W.; Perumalsamy, H.; Ahn, Y.J. Relationship between total phenolic contents and biological properties of propolis from 20 different regions in South Korea. BMC Complement. Altern. Med. 2016, 16, 65. [CrossRef] [PubMed]

24. Belina-Aldemita, M.D.; Opper, C.; Schreiner, M.; D’Amico, S. Nutritional composition of pot-pollen produced by stingless bees (Tetragonula biroi Friese) from the Philippines. J. Food Compos. Anal. 2019, 82, 103215. [CrossRef]

25. Belina-Aldemita, M.D.; Schreiner, M.; D'Amico, S. Characterization of phenolic compounds and antioxidative potential of pot-pollen produced by stingless bees (Tetragonula biroi Friese) from the Philippines. J. Food Biochem. 2020, 44, e13102. [CrossRef] [PubMed]

26. Cumbao, J.L.T.; Alvarez, P.L.J.; Belina-Aldemita, M.D.; Micor, J.R.L.; Angelia, M.R.N.; Manila-Fajardo, A.C.; Cervancia, C.R. Total phenolics, total flavonoids, antioxidant activity and antibacterial property of propolis produced by the stingless bee, Tetragonula biroi (Friese), from Laguna and Quezon, Philippines. Philipp. Entomol. 2016, 30, 63-74.

27. Barrera, W.B.J.; Brosas, J.V.; Sacil, M.D. Pollen sources of Tetragonula biroi (Friese, 1898) (Hymenoptera: Apidae, Meliponini) in two agroecosystems in Nagcarlan, Laguna, Philippines. Palynology 2020, 1-9. [CrossRef]

28. Manila-Fajardo, A.C. Pollen Contents of Apis mellifera Linn. Honey from Davao City, Philippines. J. Nat. Stud. $2012,11,96-102$.

29. Manila-Fajardo, A.C.; Cervancia, C.R. Performance of honey bees (Apis mellifera L.) In three ecosystems in Laguna, Philippines. Philipp. Agric. Sci. 2003, 86, 146-157.

30. Johnston, M.; McBride, M.; Dahiya, D.; Owusu-Apenten, R.; Nigam, P.S. Antibacterial activity of Manuka honey and its components: An overview. AIMS Microbiol. 2018, 4, 655-664. [CrossRef]

31. Oelschlaegel, S.; Gruner, M.; Wang, P.N.; Boettcher, A.; Koelling-Speer, I.; Speer, K. Classification and characterization of manuka honeys based on phenolic compounds and methylglyoxal. J. Agric. Food Chem. 2012, 60, 7229-7237. [CrossRef] [PubMed]

32. Montenegro-Burke, J.R.; Guijas, C.; Siuzdak, G. METLIN: A Tandem Mass Spectral Library of Standards. Methods Mol. Biol. 2020, 2104, 149-163. [PubMed]

33. Zulkhairi Amin, F.A.; Sabri, S.; Mohammad, S.M.; Ismail, M.; Chan, K.W.; Ismail, N.; Norhaizan, M.E.; Zawawi, N. Therapeutic properties of stingless bee honey in comparison with European bee honey. Adv. Pharmacol. Sci. 2018, 2018, 6179596. [CrossRef] [PubMed]

34. Ewnetu, Y.; Lemma, W.; Birhane, N. Antibacterial effects of Apis mellifera and stingless bees honeys on susceptible and resistant strains of Escherichia coli, Staphylococcus aureus and Klebsiella pneumoniae in Gondar, Northwest Ethiopia. BMC Complement. Altern. Med. 2013, 13, 269. [CrossRef] [PubMed]

35. Ahmed, S.; Othman, N.H. Review of the medicinal effects of tualang honey and a comparison with manuka honey. Malays. J. Med. Sci. 2013, 20, 6-13. [PubMed]

36. Mirzoeva, O.K.; Grishanin, R.N.; Calder, P.C. Antimicrobial action of propolis and some of its components: The effects on growth, membrane potential and motility of bacteria. Microbiol. Res. 1997, 152, 239-246. [CrossRef]

37. Jiang, L.; Li, H.; Wang, L.; Song, Z.; Shi, L.; Li, W.; Deng, X.; Wang, J. Isorhamnetin attenuates Staphylococcus aureus-induced lung cell injury by inhibiting alpha-hemolysin expression. J. Microbiol. Biotechnol. 2016, 26, 596-602. [CrossRef]

38. Tagousop, C.N.; Tamokou, J.D.; Ekom, S.E.; Ngnokam, D.; Voutquenne-Nazabadioko, L. Antimicrobial activities of flavonoid glycosides from Graptophyllum grandulosum and their mechanism of antibacterial action. BMC Complement. Altern. Med. 2018, 18, 252. [CrossRef]

39. Sabbagh, G.; Berakdar, N. Docking studies of flavonoid compounds as inhibitors of $\beta$-ketoacyl acyl carrier protein synthase I (Kas I) of Escherichia coli. J. Mol. Graph Model. 2015, 61, 214-223. [CrossRef]

40. Mavric, E.; Wittmann, S.; Barth, G.; Henle, T. Identification and quantification of methylglyoxal as the dominant antibacterial constituent of Manuka (Leptospermum scoparium) honeys from New Zealand. Mol. Nutr. Food Res. 2008, 52, 483-489. [CrossRef] 
41. Lane, J.A.; Calonne, J.; Slattery, H.; Hickey, R.M. Oligosaccharides isolated from MGO ${ }^{\mathrm{TM}}$ Manuka honey inhibit the adhesion of Pseudomonas aeruginosa, Escherichia coli O157:H7 and Staphylococcus Aureus to human HT-29 cells. Foods 2019, 8, 446. [CrossRef]

42. Taylor, M.A.; Robertson, A.W.; Biggs, P.J.; Richards, K.K.; Jones, D.F.; Parkar, S.G. The effect of carbohydrate sources: Sucrose, invert sugar and components of mānuka honey, on core bacteria in the digestive tract of adult honey bees (Apis mellifera). PLoS ONE 2019, 14, e0225845. [CrossRef] [PubMed]

43. Alzahrani, H.A.; Alsabehi, R.; Boukraâ, L.; Abdellah, F.; Bellik, Y.; Bakhotmah, B.A. Antibacterial and antioxidant potency of floral honeys from different botanical and geographical origins. Molecules 2012, 17, 10540-10549. [CrossRef] [PubMed]

44. Maldonado-Celis, M.E.; Yahia, E.M.; Bedoya, R.; Landázuri, P.; Loango, N.; Aguillón, J.; Restrepo, B.; Guerrero Ospina, J.C. Chemical composition of mango (Mangifera indica L.) fruit: Nutritional and phytochemical compounds. Front. Plant Sci. 2019, 10, 1073. [CrossRef] [PubMed]

45. Coelho, E.M.; de Souza, M.E.A.O.; Corrêa, L.C.; Viana, A.C.; de Azevêdo, L.C.; Dos Santos Lima, M. Bioactive compounds and antioxidant activity of mango peel liqueurs (Mangifera indica L.) produced by different methods of maceration. Antioxidants 2019, 8, 102. [CrossRef] [PubMed]

46. Ssonko, U.; Muranga, F. Phenolic compounds identification and antioxidant activity in bananas of AAB and ABB genomes grown in Uganda. J. Food Nutr. Popul. Health 2020, 4, 17.

47. Ranneh, Y.; Ali, F.; Zarei, M.; Akim, A.M.; Hamid, H.A.; Khazaai, H. Malaysian stingless bee and Tualang honeys: A comparative characterization of total antioxidant capacity and phenolic profile using liquid chromatography-mass spectrometry. LWT 2018, 89, 1-9. [CrossRef]

48. Tran, T.D.; Ogbourne, S.M.; Brooks, P.R.; Sánchez-Cruz, N.; Medina-Franco, J.L.; Quinn, R.J. Lessons from exploring chemical space and chemical diversity of propolis components. Int. J. Mol. Sci. 2020, 21, 4988. [CrossRef]

49. Popova, M.; Trusheva, B.; Bankova, V. Propolis of stingless bees: A phytochemist's guide through the jungle of tropical biodiversity. Phytomedicine 2019, 153098. [CrossRef]

50. de Paula, G.T.; Menezes, C.; Pupo, M.T.; Rosa, C.A. Stingless bees and microbial interactions. Curr. Opin. Insect. Sci. 2020, 44, 41-47. [CrossRef]

51. Massaro, F.C.; Brooks, P.R.; Wallace, H.M.; Russell, F.D. Cerumen of Australian stingless bees (Tetragonula carbonaria): Gas chromatography-mass spectrometry fingerprints and potential anti-inflammatory properties. Naturwissenschaften 2011, 98, 329-337. [CrossRef]

52. Al-Hatamleh, M.A.I.; Boer, J.C.; Wilson, K.L.; Plebanski, M.; Mohamud, R.; Mustafa, M.Z. Antioxidant-based medicinal properties of stingless bee products: Recent progress and future directions. Biomolecules 2020, 10, 923. [CrossRef] [PubMed]

53. Freitas, M.O.; Ponte, F.A.F.; Lima, M.A.S.; Silveira, E.R. Flavonoids and triterpenes from the nest of the stingless bee Trigiona spinipes. J. Braz. Chem. Soc. 2008, 19, 532-535. [CrossRef]

54. Souza, E.; Menezes, C.; Flach, A. Stingless bee honey (Hymenoptera, Apidae, Meliponini): A review of quality control, chemical profile, and biological potential. Apidologie 2021, 1-20. [CrossRef]

55. Miyata, R.; Sahlan, M.; Ishikawa, Y.; Hashimoto, H.; Honda, S.; Kumazawa, S. Propolis components from stingless bees collected on South Sulawesi, Indonesia, and their xanthine oxidase inhibitory activity. J. Nat. Prod. 2019, 82, 205-210. [CrossRef] [PubMed]

56. Kustiawan, P.M.; Phuwapraisirisan, P.; Puthong, S.; Palaga, T.; Arung, E.T.; Chanchao, C. Propolis from the stingless bee Trigona incisa from East Kalimantan, Indonesia, induces in vitro cytotoxicity and apoptosis in cancer cell lines. Asian Pac. J. Cancer Prev. 2015, 16, 6581-6589. [CrossRef] [PubMed]

57. Massaro, C.F.; Katouli, M.; Grkovic, T.; Vu, H.; Quinn, R.J.; Heard, T.A.; Carvalho, C.; Manley-Harris, M.; Wallace, H.M.; Brooks, P. Anti-staphylococcal activity of C-methyl flavanones from propolis of Australian stingless bees (Tetragonula carbonaria) and fruit resins of Corymbia torelliana (Myrtaceae). Fitoterapia 2014, 95, 247-257. [CrossRef] [PubMed]

58. Ferreres, F.; Tomáas-Barberáan, F.A.; Gil, M.A.I.; Tomáas-Lorente, F. An HPLC technique for flavonoid analysis in honey. J. Sci. Food. Agric. 1991, 56, 49-56. [CrossRef]

59. Fitsiou, E.; Mitropoulou, G.; Spyridopoulou, K.; Tiptiri-Kourpeti, A.; Vamvakias, M.; Bardouki, H.; Panayiotidis, M.; Galanis, A.; Kourkoutas, Y.; Chlichlia, K.; et al. Phytochemical profile and evaluation of the biological activities of essential oils derived from the Greek aromatic plant species Ocimum basilicum, Mentha spicata, Pimpinella anisum and Fortunella margarita. Molecules 2016, 21, 1069. [CrossRef] [PubMed]

60. Sánchez-Rangel, J.; Benavides, J.; Heredia, J.; Cisneros-Zevallos, L.; Jacobo-Velázquez, D. The Folin-Ciocalteu assay revisited: Improvement of its specificity for total phenolic content determination. Anal. Methods 2013, 5, 5990-5999. [CrossRef]

61. Kumaravelu, C.; Gopal, A. Detection and quantification of adulteration in honey through near infrared spectroscopy. Int. J. Food Prop. 2015, 18, 1930-1935. [CrossRef]

62. Oroian, M.; Ropciuc, S.; Paduret, S. Honey adulteration detection using raman spectroscopy. Food Anal. Methods 2018, 11, 959-968. [CrossRef]

63. Rios-Corripio, M.; Rios-Leal, E.; Rojas-López, M.; Delgado-Macuil, R. FTIR characterization of Mexican honey and its adulteration with sugar syrups by using chemometric methods. J. Phys. Conf. Ser. 2011, 274, 012098. [CrossRef]

64. Lu, X.; Ross, C.F.; Powers, J.R.; Aston, D.E.; Rasco, B.A. Determination of total phenolic content and antioxidant activity of garlic (Allium sativum) and elephant garlic (Allium ampeloprasum) by attenuated total reflectance-Fourier transformed infrared spectroscopy. J. Agric. Food Chem. 2011, 59, 5215-5221. [CrossRef] [PubMed] 
65. Dalisay, D.S.; Williams, D.E.; Wang, X.L.; Centko, R.; Chen, J.; Andersen, R.J. Marine sediment-derived Streptomyces bacteria from British Columbia, Canada are a promising microbiota resource for the discovery of antimicrobial natural products. PLoS ONE 2013, 8, e77078. [CrossRef]

66. Saldanha, A.J. Java Treeview-Extensible visualization of microarray data. Bioinformatics 2004, 20, 3246-3248. [CrossRef] 